\title{
MOOD OF PERSUASION IN THE ARTICLES JUST TERROR TACTICS ISSUED IN THE RUMIYAH MAGAZINE
}

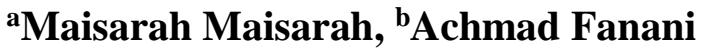 \\ Universitas Pesantren Tinggi Darul Ulum Jombang \\ e-mail: maisarah@fbs.unipdu.ac.id
}

\begin{abstract}
This research was to reveal the mood types of the clauses and the persuasion strategies applied in two texts in Rumiyah magazine. A discourse analysis was applied with the Hallidayan Systemic Functional Linguistics theory as the basis of analysis. The results showed that the texts are dominated by the declarative mood that functions as indirect directives and statements of opinion. The applied types of mood indicate that the author takes a position as the bearer of information. In the analytical part of the texts, the disclaimer technique is used to assure the readers that committing a terror is easy. In the hortatory part of the texts, the technique of suggestion is used by providing recommendations to the readers of how to do a terror operation. However, some clauses containing augmentation reflect the expertise technique of persuasion.
\end{abstract}

Keywords: Linguistics; Systemic Functional Linguistics; Mood; Speech-function realization; Persuasion. 


\section{INTRODUCTION}

Al-Hayat Media Center is the ISIS's (Islamic State of Iraq and Syria) media wing that has been publishing numerous propaganda magazines that are published online, e.g., Rumiyah and Dabiq. The propaganda magazines are written in many languages, which are to target readers outside Arab countries. The magazines are used as one of the means for recruiting foreign combatants from around the world (Wozniak et. Al., 2020; Bisgin et. Al., 2019; Lakomy, 2019; Vergani and Bliuc, 2015). Even according to Lieberman (2017), ISIS's online propaganda of terrorism is proved lethal.

According to Vergani and Bliuc (2015) ISIS has already been able to recruit more overseas fighters compared to other jihadist groups. Not only from Arab or Asian countries, ISIS has also effectively recruited fighters from western countries. European Union explained that ISIS was the most effective jihadist group in recruiting young fighters from Western countries (Archick et al., 2015).

This implies that the language ISIS used must be very powerful and properly delivered because of their successfulness in attracting many recruits all over the world. In this case, ISIS must have effectively used certain linguistic techniques or strategies to get the readers agree with their ideas and do what they are instructed to do. Wardhaugh $(2006,104)$ explains that "a change of topic requires a change in the language used" which indicates that various linguistic strategies of persuasion must have been used for various themes or purposes. For example, asking someone to conduct a terror certainly require different linguistic strategies from asking the same person to perform everyday tasks as a Muslim.

Some scholars had been interested in studying he powerfulness of ISIS' language (Ozerena et al., 2018; Mahood and Rane, 2017; Wignell, et al., 2017; Vergani and Bliuc, 2015; and Georges, 2015). However, they were concerned with word analysis rather than grammar analysis. In fact, power words are not sufficient to persuade others. To make the words more influential, they must be well organized into proper clauses/sentences. In short, we can say that in persuasion, grammar is indispensable (Power, 1998; Hogan and Speakman, 2006; Pishghadam, Ebrahimi, Meidani and Derakhshan, 2020). To effectively order, direct, guide, or persuade others, we should select clause/sentence patterns correctly. Hence, this present research dealt with the grammatical analysis of the clauses in ISIS's magazine 'Rumiyah'.

The main concern of this present research was to reveal the types of the mood and speech function realization of the clauses and reveal how the findings reflect the persuasion technique used to persuade readers to do terrors. The texts chosen for analysis were two articles entitled 'Just Terror Tactics - Part 1' and 'Just Terror Tactics - Part 2' that exists in Rumiyah the 2nd and 3rd edition, respectively. In this article, ISIS assured that the adversities faced by Muslims must be retaliated by counteracting fighting. Therefore, ISIS in the articles asked their sympathizers to play a part in knife and vehicle attacks to terrorize the enemies of Islam in their own lands. The articles give thorough procedures of how to use knives and vehicles to commit a terror, including how to get knives and vehicles, types of knives and vehicles to use or avoid, the target of the attacks, and what should be avoided when using a knife or vehicle in a terror operation. 


\section{THEORY}

\section{The System of Mood}

Hallidayan Systemic Functional Linguistics (SFL) views language as a set of semantic choices (Bloor and Bloor, 2004, Tajvidi and Arjani, 2017), which includes three metafunctions. One of them is the interpersonal metafunction which becomes the concerns of this current research. In the interpersonal metafunction, one of the main discussions is the mood system.

Halliday (2014) explains that a mood system includes two basic concepts. The first is indicative mood (negotiation of a proposition) that involves declarative and interrogative mood and the second is imperative (negotiation of a proposal) that involves imperative mood. Typically, a declarative mood functions as a statement (of facts, opinion, etc.) giving information. An interrogative is typically the mood of the question, asking for information (Halliday, 2014; Eggins, 2004). An imperative is the mood of the verb and the principal mood of will and desire (Lyons, 1977) which typically functions as orders, requests, and directives (Eggins, 2004). The imperative mood is performative (Palmer, 2001).

The type of a mood, however, does not always conform with its typical speechfunction. For example, a declarative or a question may function as a directive as in 'You should wait here' or 'Would you please wait here?', asking the hearer to wait.

Many scholars such as Lilian (2008); Ayoola (2013); Jalali (2014); Kondowe (2014); Al- Ameedi (2015); Lirola (2016); Milkovich (2017) had researched the language of political propaganda from the mood perspective. However, the analyses commonly relate only to uncovering the types of mood and the reasons for their application in persuasion. Ayoola (2013), for example, has carried out a study of the interpersonal meaning (the mood system) of selected advertisements of two political parties during the last general election in Nigeria. He found out that the interpersonal meaning of a structure was not always consistent with its lexicogrammar analysis.

\section{Persuasion: Definition}

There are some definitions about persuasion. For example, Gass and Seiter (2010) argues that persuasion is generally intended for influencing the beliefs, attitudes, intentions, motivations, or behaviors of the target auidenece/readers. Persuasion according to Simons et al., (2001) is the human communication intended to persuade the independent judgments and actions of others. Dillard and Pfau (2002) give another definition about persuasion, according to them, it is a symbolic transaction that uses "reason and/or emotional appeals" to change the others' behavior. In general, we can say that persuasion is an effort to alter the behavior and opinion of others.

\section{Persuasion: Types of persuasive texts}

A persuasive text or an argumentative or expository text is defined as a form of rhetorical production that includes "the identification of a thesis or claim, the establishing of supportive evidence, and the evaluation of warrants that connect the thesis, evidence and subject matter of the argument" (Newell, Beach and Smith, 2011). Coffin (2004) explained that there are two terms usually used to differentiate the purposes and strategy of persuasion, namely analytical and hortatory expositions. An 'analytical exposition' text is aimed at "persuading that". The nature of the relationship 
between writer and the reader in this text is interpersonally separated. The social function of an analytical text is to assure the readers or audience that something needs attention and is imperative. Besides it also has a social function of convincing the readers that the opinion is true and supported by strong evidences.

In contrast, a 'hortatory exposition' is used for "persuading to", convincing the readers to do or conduct something in a specific way - performing a social action. In such persuasive texts, the nature of the relationship between readers/audience and writer/speaker is often closer (Coffin, 2004). In this kind of Text, the writer provides his opinions and arguments to support the topic of the text. The recommendation is commonly put at the end of the text. Here the writer/speaker asks and convinces the readers/audience to do something.

\section{METHOD}

This present study applied a discourse analysis with qualitative approach to identify how the grammar (i.e., the types of mood and the realizations of speechfunction) was played in order to persuade the target readers. The data sources (the articles "Just Terror Tactics - Part 1" and "Just Terror Tactics - Part 2") were got from the second and third editions of ISIS' magazine (Rumiyah), respectively. There were 51 major clauses (data) that were analyzed in the first text while there were 48 major clauses (data) that were analyzed in the second text. In this present research, every simple sentence or complex sentence was calculated as one clause. On the other hand, a compound sentence was treated differently. It was calculated depending on the clauses that construct the sentence. Therefore, a compound sentence that consists of two major (main) clauses was calculated as two clauses, and so on. The data collected were then processed and analyzed to identify the mood types and their realizations of speech-function. The discussion was stressed on how the major findings (the mood types and their speech-function realizations) reflect the persuasion strategies applied in the texts.

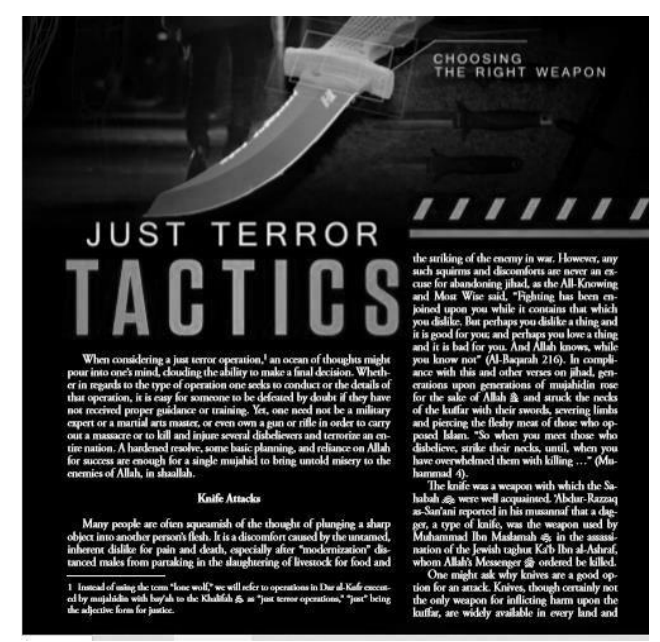

Figure 1: The first page of the article "Just Terror Tactics - Part 1" (Rumiyah, the second edition)

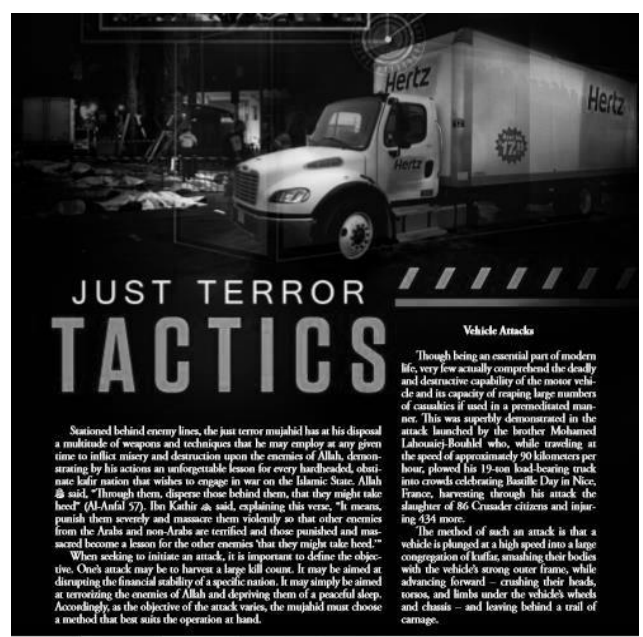

Figure 2: The first page of the article "Just Terror Tactics - Part 2" (Rumiyah, the third edition) 


\section{RESULTS AND DISCUSSION}

\section{Results}

Table 1 below shows the mood type and its speech-function realizations of the main clauses that are present in the first text.

Table 1: Mood types and speech-function realizations of the clauses of persuasion in text 1

\begin{tabular}{|c|c|c|c|c|}
\hline $\begin{array}{l}\text { Mood } \\
\text { type }\end{array}$ & $\begin{array}{c}\text { Speech } \\
\text { Function } \\
\text { Realization }\end{array}$ & $\begin{array}{l}\text { Model of } \\
\text { presentation }\end{array}$ & $\begin{array}{c}\text { Important } \\
\text { element of clause }\end{array}$ & Clauses \\
\hline \multirow{7}{*}{ Declarative } & \multirow{2}{*}{$\begin{array}{l}\text { Indirect } \\
\text { directive }\end{array}$} & - DASDS & $\begin{array}{l}\text { - Finite (modal } \\
\text { verbs) } \\
\text { - Clause-like } \\
\text { adjunct }\end{array}$ & $\begin{array}{l}\text { Clause 13, Clause 14, } \\
\text { Clause 15, Clause 19, } \\
\text { Clause 26, Clause 28, } \\
\text { Clause 30, Clause 31, } \\
\text { Clause 35, Clause 37, } \\
\text { Clause 39, Clause 41, } \\
\text { Clause 42, Clause 49 }\end{array}$ \\
\hline & & - TASAU & $\begin{array}{l}\text { - } \text { Adjunct (if- } \\
\text { clause) } \\
\text { - Finite (modal } \\
\text { verbs) } \\
\text { - Complement }\end{array}$ & $\begin{array}{l}\text { Clause 34, Clause 16, } \\
\text { Clause 18, Clause 20, } \\
\text { Clause 21, Clause 22, } \\
\text { Clause 24, Clause 27, } \\
\text { Clause 29, Clause 32, } \\
\text { Clause 33, Clause 47, } \\
\text { Clause 48 }\end{array}$ \\
\hline & \multirow[b]{2}{*}{$\begin{array}{l}\text { Statement } \\
\text { of } \\
\text { Opinion }\end{array}$} & - $\mathrm{PCS}$ & - Complement & $\begin{array}{l}\text { Clause 11, Clause 12, } \\
\text { Clause 23 }\end{array}$ \\
\hline & & - GEOS & $\begin{array}{l}\text { - Complement } \\
\text { - Adjunct } \\
\text { - Finite }\end{array}$ & $\begin{array}{l}\text { Clause 01, Clause 02, } \\
\text { Clause 03, Clause 04, } \\
\text { Clause 05, Clause 06, } \\
\text { Clause 07, Clause 25, } \\
\text { Clause 36, Clause 38, } \\
\text { Clause 40, Clause 43, } \\
\text { Clause 44, Clause 45, } \\
\text { Clause 46, Clause 50 }\end{array}$ \\
\hline & \multirow{2}{*}{$\begin{array}{r}\text { Statement } \\
\text { of fact }\end{array}$} & - TPE & - Complement & Clause 08 \\
\hline & & - TSSS & - Subject & Clause 09 \\
\hline & Question & $\begin{array}{l}\text { - Indirect } \\
\text { question }\end{array}$ & - Complement & Clause 10 \\
\hline Imperative & $\begin{array}{c}\text { Direct } \\
\text { directive }\end{array}$ & $\begin{array}{l}\text { - Unmarked } \\
\text { imperative } \\
\text { mood }\end{array}$ & - Complement & Clause 51 \\
\hline
\end{tabular}

Note: DASDS (Directly advising someone to do or avoid something), TASAU (Talking about something advised to use/not to use), PCS (Presenting the characteristic of something), GEOS (Giving an evaluative opinion of something), TPE (Telling Past Events), TSSS (Telling about someone saying something)

Table 1 tells that there are two moods used by the author to compose the text: declarative mood and imperative mood. The declarative mood is utilized to exchange information to readers. In this context, it is used to make statements with different functions: indirect directives (the dominant one), statements of opinion, and a question. 
To compose indirect directives from declarative mood, Rumiyah commonly applies them as advice (suggestions). To do so, the following two models of presentation are applied:

1) DASDS (Directly advising someone to do or avoid something)

2) TASAU (Talking about something advised to use/not to use)

The first model of presentation (DASDS) is applied by employing some modal verbs indicating advice like "should" or "could". This model directly asks the readers (though the pronoun 'one' instead of 'you' in this text is used to refer to the readers) to do certain things in specific ways. This model gives a stronger emphasis on what should be done/avoid. For example, Clause 14 gives information of what should be done first when choosing a knife for terror operation. In this instance, it is suggested that readers should focus firstly on the sharpness of the knives. Although on the surface the declarative clause is a statement, but it can be categorized as an indirect directive instruction because a suggestion is principally an instruction to do or avoid something. For example, when someone says, "You should take the book.", then it is actually a command or direction to the hearer to take the book. In other words, the suggestive clause is equal to a more blatant command "Firstly, focus on sharpness when you choose a knife."

Clause 28 denotes another example in which Rumiyah presents an alternative of choosing the target when doing a knife terror. In this instance, the readers are suggested to target lone victims as an alternative for the small crowd. Again, though superficially the clause is informative, it is suggestive in nature. The modal verb 'may' in the clause indicates a suggestion or permission to do something. Therefore, the suggestion is equal to a stronger instruction as "Target lone victims when you pursue a prolonged campaign of terror."

Rumiyah also applies subjunctive expressions like 'it is advised to' or 'it is advised that' to make a suggestion to do something. For example, in Clause 35 the readers are advised not to stab the head of the targeted victim because the skull is hard naturally. The word 'advised' in the clause indicates a recommendation that indirectly instructs the readers not to do something.

Likewise, the second model (TASAU) is frequently applied in this text. This model puts the advised thing as the theme (subject) of the clause, therefore softer than the first model. For example, in Clause 22 the subject 'folding knives' becomes the theme of the clause, which means it is the emphasis of discussion. As the theme, the readers would be directly oriented to it and see what should be done with folding knives. Again, though it is superficially declarative mood, but the speech function of the clause is a suggestion to do something so that directive in nature. In this example, the declarative mood of suggestion is equal to the more obtrusive imperative mood "Don't use folding knives."

Another example is Clause 27 in which Rumiyah makes a statement about the target and uses it as a recommendation to the readers when choosing the target of terror. This clause is undoubtedly a more subtle way of asking the readers to do something and is comparable to an imperative mood "choose a smaller crowd ..."

In this model, the advice is reflected in some ways: First, the suggestion is used very subtly using an 'if clause' pattern as in Clause 21. The clause 'If it lacks a guard' orients the readers of what kind of knife that should be avoided in doing terror, which is, in this instance, the knife with no guard.

Second, the modal verb 'should' is employed to make an indirect instruction. For instance, Clause 16 uses the modal verb 'should' to indicate that something should (not) be in a particular feature. In this instance, the kinds of knives that should be avoided in committing a knife terror are described. In Clause 22, the modal 'should' is explicitly followed by 'be avoided' to make the suggestion more evident to the readers.

Third, the indirect instruction is also reflected in the element of complement. In this case, the pattern of 'something is not a good option' is applied. For example, Clause 23 informs that knives that have a "lockback" or spine lock should not be used in a knife terror operation. 
The readers are suggested not to use them because the result would not be satisfying. Though it only talks about something, but implicitly, it is a suggestion to the readers. The construction is comparable to a more explicit suggestion as 'you should not use knives that have a "lockback" or spine lock to do a knife terror.'

In composing the statements of opinion, Rumiyah uses 17 declarative clauses in the first text of Theme 2. To present them, there are two models applied:

1) PCS (Presenting the characteristic of something)

2) GEOS (Giving an evaluative opinion of something)

The first model (PCS) is applied by describing the characteristics of something. The description, commonly located in the element of complement, represents Rumiyah's stance of something. For example, in Clause 11 the complement of the clause tells the readers that knives are widely available and are readily accessible. Another example is Clause 12 where the complement of the clause gives a further explanation about the effectiveness of knives for terror operation. In its opinion, knives are handy to use as a means of terror because they are easy to conceal and highly lethal.

The second model, GEOS, is applied to represent Rumiyah's personal evaluation about an occurrence or a specific condition. Again this model is used to describe a stance or opinion of something, whether a particular thing or event is good, bad, adequate, or in another condition. For example, in Clause 04 the complement 'enough' indicates an evaluative opinion that a mujahid does not need significant supplies of weapons to attain a successful terror operation. What he needs are just a hardened resolve, some basic planning, and reliance on Allah. Another example is Clause 25 where Rumiyah compares the variables in the clause to show its evaluative opinion that choosing a target of terror is similar to hunting prey. In its opinion, both of them need a thorough consideration to get a satisfying result.

In text 1, only two declarative clauses function as statements of fact which are delivered in two models of presentation: TPE (Telling Past Events) and TSSS (Telling about someone saying something). The first model is represented by Clause 08 , strengthening an argumentation that a knife is a common yet effective device for fighting and killing because it was generally used by sahabah. The second model is represented by Clause 09 which is constructed in a reported speech. The clause is used to give an example of how a dagger, a type of knife, was used by a sahabah to kill an enemy of Islam.

In text 1 , one declarative clause is used to function as a question (Clause 10). The complement of the clause 'why knives are ...' bears the central message of the clause. Although the clause is written in declarative mood, it is equal to an interrogative, "Why do knives are a good option for an attack?" This question is utilized as an opening to further explanation of the effectiveness of knives as a tool for committing a "just terror operation."

Besides declarative, as the major mood type composing the text, one clause, i.e., Clause 51 , is overtly written in an unmarked imperative mood. In line with the typical function of an imperative mood, the clause functions as a direct directive (instruction) to the readers. The complement of the clause 'Allah's Messenger said ...' is the core of the clause message. Rumiyah uses it to close the text, asking the readers to remember what Prophet Muhammad said about the position of a kafir and his killer. This is a strong closing because it is aimed at strengthening the readers' conviction in doing a terror.

Table 2 shows the mood type and its speech-function realizations of the main clauses that are present in the second text. 
Table 2: Mood types and speech-function realizations of the clauses of persuasion in text 2

\begin{tabular}{|c|c|c|c|c|}
\hline $\begin{array}{l}\text { Mood } \\
\text { type }\end{array}$ & $\begin{array}{c}\text { Speech } \\
\text { Function } \\
\text { Realization }\end{array}$ & $\begin{array}{c}\text { Model of } \\
\text { presentation }\end{array}$ & $\begin{array}{l}\text { Important } \\
\text { element of } \\
\text { clause }\end{array}$ & Clauses \\
\hline \multirow[t]{7}{*}{ Declarative } & \multirow{3}{*}{$\begin{array}{l}\text { Statement } \\
\text { of } \\
\text { Opinion }\end{array}$} & - PPDS & - Complement & $\begin{array}{l}\text { Clause 05, Clause 06, } \\
\text { Clause } 07\end{array}$ \\
\hline & & - GEOS & $\begin{array}{l}\text { - Adjunct } \\
\text { - Predicator } \\
\text { - Complement } \\
\text { - Finite }\end{array}$ & $\begin{array}{l}\text { Clause 09, Clause 12, } \\
\text { Clause 13, Clause 14, } \\
\text { Clause 15, Clause 16, Clause } \\
\text { 17, Clause 18, Clause 19, } \\
\text { Clause 20, } \\
\text { Clause 21, Clause 22, } \\
\text { Clause 23, Clause 24, } \\
\text { Clause 29, Clause 34, Clause } \\
\text { 35, Clause 42, Clause 43, } \\
\text { Clause 44, Clause 46, Clause } \\
45\end{array}$ \\
\hline & & - PCS & $\begin{array}{l}\text { - Predicator } \\
\text { - complement }\end{array}$ & Clause 01, Clause 11 \\
\hline & \multirow[t]{2}{*}{$\begin{array}{l}\text { Indirect } \\
\text { directive }\end{array}$} & - DASDS & $\begin{array}{l}\text { - finite } \\
\text { (modal } \\
\text { verb) } \\
\text { - clause- } \\
\text { like } \\
\text { adjunct }\end{array}$ & $\begin{array}{l}\text { Clause 04, Clause 08, } \\
\text { Clause 25, Clause 26, } \\
\text { Clause 27, Clause 28, Clause } \\
\text { 30, Clause 33, Clause 37, } \\
\text { Clause 38, Clause 39, Clause } \\
\text { 40, Clause 41, Clause 47, } \\
\text { Clause 48 }\end{array}$ \\
\hline & & - TASAD & $\begin{array}{l}\text { - Subject } \\
\text { - Finite } \\
\text { (modal verb) } \\
\text { - Complement }\end{array}$ & $\begin{array}{l}\text { Clause 31, Clause 32, Clause } \\
36\end{array}$ \\
\hline & \multirow{2}{*}{$\begin{array}{r}\text { Statement } \\
\text { of fact }\end{array}$} & $\bullet$ TPE & - adjunct & Clause 10 \\
\hline & & - TSSS & - Subject & $\begin{array}{l}\text { Clause } 02 \\
\text { Clause } 03\end{array}$ \\
\hline
\end{tabular}

Note: PPDS (Presenting the purpose of doing something), GEOS (Giving evaluative opinion of something), PCS (Presenting the characteristics of something), DASDS (Directly advising someone to do something), TASAD (Talking about something advised to do/not to do), TPE (Telling past events), TSSS (Telling about someone saying something)

As displayed in the table above, 48 main clauses are composing the text, and all of them are delivered in declarative mood. The declarative clauses in this text are utilized to exchange commodities (information) to the readers. In this context, they are statements with different functions: statements of opinion (26 clauses), indirect directives (18 clauses), and statements of fact (4 clauses).

In composing the statements of opinion, three models of presentation are applied:

1) PPDS (Presenting the purpose of doing something)

2) GEOS (Giving evaluative opinion of something)

3) PCS (Presenting the characteristics of something)

The first model (PPDS) is used to present the purpose of doing something. The patterns used in this model are 'Something is done to generate something else' and 'it may be aimed at doing something' where the element of complement indicates the objectives of doing something. By this model of presentation, the primary purpose of doing something is posed to the readers, which is one of the cores of the text messages. For example, in Clause 05 the complement tells about the purpose of conducting a terror. In Rumiyah's opinion, one of the purposes is to kill as many people (the kuffar) as possible to result in horror in the enemies' land. Similarly, the complement in Clause 
06 provides the readers with the opinion about another purpose of doing terror that is aimed at "disrupting the financial stability of a specific nation."

The second model of presentation is GEOS. As in the previous texts, this model is used to represent Rumiyah's stance of something, whether a particular thing or event is good, bad, adequate, or in another condition. For example, in Clause 15, the evaluative opinion of a vehicle as a means of terror is indicated by the complement 'one of the safest and easiest weapons'. In the same way, Clause 18 evaluates the effectiveness of smaller vehicles as a means of terror that it is incapable of granting the level of carnage that is sought. Besides, to present an opinion, a simple comparison between variables in a clause is made. For example, in Clause 12, Rumiyah compares vehicles and knives that, in its opinion, they are alike because of their easiness to acquire.

The third model is PCS which is used to describe something or someone reflecting a stance or opinion of something. The description is commonly located in the element of predicator+complement. For example, in Clause 13, Rumiyah describes the characteristics of vehicles for terror operation that, in its opinion, they will 'arouse no doubts' because of their widespread availability in every land.

Many declarative clauses in this text function as indirect directives (instructions), which are commonly wrapped as advice or suggestion, telling what should be done or avoided. As in the previous text, two models of presentation are applied:

1) DASDS (Directly Advising Someone to Do Something)

2) TASAD (Talking About Something Advised to Do/not to do)

In applying the first model, DASDS, some modal verbs indicating advice such as "should" or "could" are utilized. As in the previous text, this model is stronger than the second one because it directly asks readers to do something. For example, Clause 30 informs readers of what should be done when choosing the target of terror. In this instance, it is directly suggested that readers (perpetrators of terror) choose any outdoor attraction that draws large crowds, which may result in a significant number of casualties. Though superficially it is a statement, this declarative mood is used to ask readers to do something. Hence, it is comparable to a more obvious command "Choose any outdoor attraction that draws large crowds."

Another example is Clause 40 in which Rumiyah suggests that readers (the potential perpetrators of terror) should exit the vehicle and finish their operation on foot. Again, though it is a statement on the surface, it is a suggestion in nature. The pronoun 'one' instead of 'you' is chosen to avoid obtrusiveness to the readers. The modal verb 'may' in this clause indicates a suggestion or possibility of doing something. Though it is a statement, it is comparable to a more robust instruction "exit the vehicle and finish your operation on foot."

Besides modal verbs, subjunctive expressions like 'it is important to' or 'it is imperative that' are utilized to give advice. For example, in Clause 38 the element of adjunct is used to state the importance of doing something. It is asserted in the clause that the committer of terror not exit the vehicle when making a vehicle attack. In this sense, the clause is equal to a more robust imperative "Don't exit the vehicle during the attack." In similar way, Clause 04 indirectly asks readers to define the objective of the attack being launched.

In the second model, TASAD, Rumiyah only uses the modal verb 'should' to express suggestion to readers which is delivered indirectly. Firstly, the suggestion is about something that should be in a particular condition. For example, in Clause 32 
the word 'the target' is put as the theme of the clause and tells the readers that ideally, it should be on the road. Although it is declarative mood, the speech function of the clause is apparently a suggestion to do something; hence directive in nature. In this example, it is equal to the more apparent imperative mood "Choose the target on a road that offers the ability to accelerate to a high speed."

Secondly, the suggestion is about something that should be done in specific ways, as in Clause 36. In this instance, Rumiyah puts the phrase 'an appropriate way' as the theme of the clause and suggests that it should be determined for announcing one's allegiance to the Khalifah of the Muslims. Again, though it is declarative mood, it is in fact a suggestion to do something. This clause is undoubtedly a more subtle way of asking the readers to do something (to determine an appropriate way).

Some clauses in this text function as statements of fact. Two models are utilized to compose them: (1) TPE (Telling Past Events), and (2) TSSS (Telling about someone saying something). The first model (TPE) is exemplified by Clause 10, where an example of an event terror) conducted by Mohamed Lahouaiej-Bouhlel is presented. The adjunct 'superbly' is significant in this construction, describing how the occurrence happened. On the other hand, the second model (TSSS) is represented by Clause 03 in which Rumiyah, through a direct quotation, tells the readers about a statement from Ibn Kathir, a great Muslim scholar, about the explanation of an ayah.

\section{DISCUSSION}

The texts analyzed: "Just Terror Tactics - Part 1" and "Just Terror Tactics Part 2" are written for ISIS's sympathizers around the world, especially those in western countries. They are those who did not have the ability to fight directly on the battlefield in the Middle East but had a strong desire to struggle in the way of Allah. The main purpose of the texts is to convince that such terrors were just retaliation to what the soldiers of the infidel countries did in the IS's territories.

The texts (especially text 1) are not only used to persuade that something is imperative and needs to get attention (analytical exposition) but also to direct someone to do something (hortatory exposition). In general, the texts are dominated by the declarative mood that functions as indirect directives (DASDS and TASAD models) and statement of opinion (PCS and GEOS models). The applied types of mood indicate that Rumiyah seems to positions itself as the bearer of information to the readers. The information is delivered objectively as indicated by unused pronouns as 'I' or 'we'. The high use of declarative mood instead of imperative one is due to the fact that Rumiyah is talking to the readers who are relationally detached outer-group sympathizers). Their power relation is relatively equal since the readers are only ISIS's sympathizers, not the true supporters or inner-members of ISIS. It is plausible, therefore, when Rumiyah uses pronoun 'one' instead of 'you' to refer to the readers, as in Clause 19 (text 1). The selection of the pronoun signifies that Rumiyah wants to keep its distance from the readers when making suggestions.

Concerning the types of persuasive text, there is a bit difference between Text 1 and Text 2 , though both are generally aimed at persuading the readers to do something. Within Text 1, the clauses in the first three paragraphs are mainly used to persuade readers about the importance of something, while the rest is used to ask them to do something. This indicates that the text is not purely a hortatory exposition although mainly it is used to make someone do something in a certain way. Therefore, the text is appropriately be classified as an analytical-hortatory exposition. Within Text 2, the 
clauses indicating an analytical exposition are only in the first three clauses of the text while the rest of the clauses mainly function as indirect directives (instructions to do something).

The techniques used to compose the clauses vary concerning the types of text. In analytical clauses, some clauses were mainly characterized by trivialization and augmentation. The elements of adjuncts and complements in the clauses well play the functions of assuring the readers that doing terror is easy, and knives are the right weapons because they are easy to get and hide. The elements of adjuncts and complements 'also' significantly play their roles in amplifying the necessity of doing jihad, a certain situation, and a quality.

The rest of the paragraphs were mainly characterized by declarative clauses functioning as suggestions. The modulated modality (e.g., should) and subjunctive expressions (e.g., 'It is advised to' and 'It is advised that') are extensively used. Using suggestive clauses instead of imperative one is the right choice because it makes Rumiyah appear not too obtrusive to its readers. Blatant command to do something should be avoided in this case due to the fact that the risk of doing terror is very high (Leech, 1983), i.e., the loss of the perpetrator's live.

The declarative mood also plays an important role in these two texts. They shorten the distance between Rumiyah and the readers because they directly provide them with the intended information. Unlike interrogative or imperative mood, the declarative mood does not require a confirmation from the readers for the success of the proposition (Halliday, 2014; Eggins, 2004).

As for the modality, the two texts widely use the modulized modality indicating an obligation. This means that the texts are mainly aimed at presenting suggestions instructions) to do something in certain ways. The suggestive clauses mainly contain the modulized modality either in the form of a modal verb (e.g., should), a phrase (e.g., It is advised to), or a clause (e.g., It is advised that, it is imperative that). The forms (words, phrases, and clauses) referring to suggestions are deontic in nature, which indicates how the world ought to be under certain norms, expectations, speaker desires, etc. (Palmer, 2001; Lillian, 2008).

For example, the use of 'should' in Clause 30 (Text 2) indicates a certain condition that should be fulfilled when doing something. In this instance, it is suggested that a perpetrator of terror consider any outdoor attraction that draws large crowds as the target of vehicle terror. Similarly, the phrase 'it is advised to' in Clause 39 (Text 1) advises readers not to do something unless they have certain capabilities. The clause-like adjunct "It is imperative that" in Clause 38 (Text 2) presents Rumiyah's strong suggestion to a perpetrator of a vehicle attack not to exit the vehicle during the attack.

The use of declarative mood as an indirect directive or request in the two texts is interesting to discuss because of its abundant use. The use of indirect directives (suggestions) indicates that Rumiyah seems to avoid the use of direct instructions, which look too obtrusive to the readers. This is in line with Khalib and Tayeh's research (2013) that people will tend to command or request indirectly to people who are not or less familiar with it. In these texts, the relationship between Rumiyah and the readers is fairly detached as they do not know each other. Therefore, in these two texts, Rumiyah tends to be softer in directing the readers and seems to avoid what is known as Face Threatening Acts FTA), acts that threaten either the speaker's face or the hearer's face (Brown and Levinson, 1987). Held (2005) provides an explanation for indirectness in ordering: "indirectness lowers the obligations of both partners in 
interaction and thus relieves them of direct responsibility by appearing to put all the cards in the addressee's hand, indirectness [encourages] the hearer to cooperate."

Furthermore, the risk factor may also influence Rumiyah's selection of indirectness rather than directness. As explained by Leech (1983), people will be likely to give an order for action more imperceptibly if the risk factor is greater for the doer. In other words, we can say that the greater the risk, the more indirect the language of command or request used. Therefore, because the risk of the action (doing terror) is very high - the loss of the doer's life, - Rumiyah tends to resort to indirectness in giving instructions to the readers. In these texts, the modal verb 'should' and its equivalent, (e.g., may) and the clause-like adjunct 'it is advised to/that' are commonly applied to express suggestions.

In Kellermann and Cole's classification (1994), the clauses containing 'should' or 'it is advised to/that' are used to present a suggestion as one of the strategies for getting readers' compliance. The use of suggestions indicates another applied strategy that is 'expertise positive/negative)'. Rumiyah suggests that the potential doers do something based on adequate knowledge and experience on the matter of discussion (Gobet, 2015). Rumiyah tries to gain the readers' compliance by suggesting an idea that by doing/not doing so, the result will be good or bad. According to Mulholland (1994), when making a suggestion, someone has made assumptions: a) that the hearers/readers need to be advised about something. Here, Rumiyah seems to assume that the readers need useful advice on how to do a knife and vehicle terrors correctly and efficiently; b) what it is that the hearer needs to be advised about. In this case, Rumiyah seems to assume that there is some information that needs to be advised to the readers, specifically about how to use knives and vehicles for terror and what types of knives and vehicles should be used; and c) that they have the right to offer advice. In this case, Rumiyah positions itself as an expert so that it has the 'right' to give practical and valuable advice to the readers about doing terror using knives and vehicles.

Besides indirectness, two other interesting phenomena mainly characterize the text: trivialization and augmentation both in the clauses functioning as statements opinion and direct directives. In clauses containing trivialization, Rumiyah commonly uses the elements of adjuncts, complements, and modality to do it. For example, in Clause 37 (Text 2) the adjunct 'simply' gives a sense that acknowledging the motive of the attack can be done easily. Similarly, in Clause 40 (Text 1), the mood adjunct 'simply', the comment adjunct 'just as one would slaughter a sheep', and the complement 'sufficient' in the clause is used to convince the readers that the method of killing a target of terror using a knife is as simple as the method of slaughtering a goat.

Trivialization in persuasion becomes important in the process of persuasion. Based on Kellermann and Cole's compliance-gaining strategies, the elements of clauses indicating trivialization can be classified as a disclaimer strategy in which Rumiyah tries to get the others the readers) to comply by downplaying or trivializing what it is asking them to do. That is, Rumiyah tries to gain the readers' compliance by ensuring that doing terror is easy, not difficult, and shouldn't be problematic. According to Dooley (2013), someone will tend to do what we ask if it looks easy to do. Trivialization is one of the ways to 'reframe' a situation. Reframing is posing reality from a different perspective; for example, making something that is in fact difficult to do seems easy to do (Simons \& Jones, 2017). In these two texts, Rumiyah wants to tell 
the readers that committing terror using a knife or a vehicle is easy to do by anyone, involving the readers.

In clauses containing augmentation, Rumiyah uses the elements of adjuncts, subjects, and complements to make augmentation. Through the elements, Rumiyah positions itself as an expert who well understands the situation. In this case, the clauses reflect the use of an expertise strategy of persuasion (Kellermann and Cole, 1994). The author augments the positive or negative impactsor results of doing certain things.For example, in clause 11 (Text 1), the adjuncts 'widely' and 'readily' indicate that the author possesses very well knowledge about the situation. He seems to know very well that knives are very easy to get everywhere. Similarly, in clause 7 (Text 1), the author uses the modality "never" to augment the necessity of doing something (jihad) though something bad or discomfort may arise.

Regularly, in persuasive situations, a persuader tries to direct the other's attention to ideas that reinforce his/her argument and away from points that weaken his/her argument. In other words, we thus both augment the supportive points and weaken other points (Straker, 2002). Augmentation is often used in persuasion because people tend to exaggerate when offering something to others (Cialdini, 2007).

In sum, it can be inferred that in the two texts the author positions himself as the information giver and mainly wrapped the information conveyed in the form of indirect directives and statements of opinion. The author generally advises the readers to do something in certain ways. Therefore, this kind of text can be categorized asa response shaping text because it deals with forming a new behavior or attitude of the readers (Dillard and Pfau, 2002), which in this case, training someone to be a 'lonewolf' terrorist.

\section{CONCLUSION}

From the findings and discussion above it can be concluded that (1) the texts are dominated by the declarative mood that functions as indirect directives (DASDS and TASAD models) and statement of opinion (PCS and GEOS models). The applied types of mood indicate that Rumiyah has a tendency to positions itself as the deliverer of information to the readers. (2) The analytical part of the texts is characterized by the use of the disclaimer technique to persuade the readers that conducting a terror is not a difficult job. The hortatory part of the texts is characterized by the technique of suggestion that gives recommendation to the readers concerning what to do when doing a terror operation. Besides, some clauses containing augmentation reflect the use of expertise strategy of persuasion both in the analytical or hortatory parts of the texts. Overall, the two texts were mainly used to form a new behavior or attitude of the readers (response-shaping), which is to train them to be 'lone-wolf' terrorists.

\section{REFERENCES}

Al-Ameedi, R. T. (2015). A Pragmatic Study of Barak Obama's Political Propaganda. Journal of Education and Practice, 6(20), 75-86.

Archick, K., Belkin, P., Blanchard, C. M., Humud, C. E., \& Mix, D. E. (2015). European Fighters in Syria and Iraq: Assessments, Responses, and Issues for the United States. Washington, D.C: Congressional Research Service. 
Ayoola, M. O. (2013). An Interpersonal Metafunction Analysis of Some Selected Political Advertisements in Some Nigerian Newspapers. International Journal of Humanities and Social Science, 3(8), 165-178.

Azman, N. A. (2016). Islamic State (IS) Propaganda: Dabiq and Future Directions of 'Islamic State'. RSiS (S.Rajaratnam School of International Studies), 8(10), 3-8.

Bisgin H., Arslan H., Korkmaz Y. (2019) Analyzing the Dabiq Magazine: The Language and the Propaganda Structure of ISIS. In: Thomson R., Bisgin H., Dancy C., Hyder A. (eds) Social, Cultural, and Behavioral Modeling. SBPBRiMS 2019. Lecture Notes in Computer Science, vol 11549. Springer, Cham

Bloor, T., \& Bloor, M. (2004). The Functional Analysis of English (2nd ed.). New York: Oxford University Press Inc.

Coffin, C. (2004). Arguing about how the world is or how the world should be: The role of argument in IELTS Test. Journal of English for Academic Purposes, 3(3), 229-246.

Dillard, J. P., \& Pfau, M. (2002). The Persuasion Handbook: Developments in Theory and Practice. Thousand Oaks, CA: Sage Publications.

Dooley, R. (2013, April 22). https://www.forbes.com/sites/rogerdooley/2013. Retrieved $8 \quad 10, \quad 2019$, from https://www.forbes.com: https://www.forbes.com/sites/rogerdooley/2013/04/22/the-easy-path-topersuasion/\#75a095b6333a

Eggins, S. (2004). Introduction to Systemic Functional Linguistics. New York: Continuum.

Gass, R. H., \& Seiter, J. S. (2010). Persuasion, social influence, and compliance gaining (4th ed.). Boston: Allyn \& Bacon.

Georges, A. (2015). ISIS Rhetoric for the Creation of the Ummah. Abu Dhabi: TRENDS Research \& Advisory.

Halliday, M. (2014). Introduction to Functional Grammar. New York: Routledge.

Held, G. (2005). Politeness in linguistic research. In S. I. Richard J. Watts, Politeness in language: Studies in its history, theory and practice (pp. 131-153). Berlin: Mouton de Gruyter.

Hogan, K., \& Speakman, J. (2006). Covert Persuasion, Psychological Tactics and Tricks to Win the Game. New Jersey: John Wiley \& Sons, Inc.

Jalali, M. S. (2014). A Critical Discourse Analysis of Political Speech of Four Candidates of Rasht City Council Elections in 2013, with a view to Fairclough Approach. European Journal of Social Sciences Education and Research, 1(2), 8-18. 
Kellermann, K., \& Cole, T. (1994). Classifying compliance gaining messages: Taxonomic disorder and strategic confusion. Communication Theory, 4(1), 3-60.

Khalib, F. M., \& Tayeh, A. (2013). Indirectness in English requests among Malay university students. Procedia, 134(2014), 44-52.

Kondowe, W. (2014). Interpersonal Metafunctions in Bingu wa Mutharika's SecondTerm Political Discourse: A SystemicFunctional Grammatical Approach. International Journal of Linguistics, 6(3), 70-84.

Lakomy, M. (2018): "One of the Two Good Outcomes": Turning Defeats into Victories in the Islamic State's Flagship Magazine Rumiyah, Terrorism and Political Violence, 1-19: DOI: 10.1080/09546553.2018.1506335

Lieberman, A. V. (2017). Terrorism, the Internet, and Propaganda: A Deadly Combination. Journal of National Security Law \& Policy, 9(95): 95-124.

Lillian, D. L. (2008). Modality, Persuasion and Manipulation in Canadian Conservative Discourse. Critical Approaches to Discourse Analysis across Disciplines (CADAAD), 2(1), 1-16.

Lirola, M. M. (2016 ). Multimodal analysis of a sample of political posters in Ireland during and after the Celtic Tiger. Revista Signos. Estudios de lingüística, 49(91), 245-267.

Lyons, J. (1977). Semantics. Cambridge: Cambridge University Press.

Mahood, S., \& Rane, H. (2017). Islamist narratives in ISIS recruitment propaganda. The Journal of International Communication, 23(1): 15-35, DOI: 10.1080/13216597.2016.1263231.

Milkovich, M. (2017). Epistemic Modality in Political Discourse. Research Result. Social Studies and Humanities, 3(1), 75-79.

Mulholland, J. (1994). Handbook of persuasive tactics, A practical language guide. London and New York: Routledge.

Newell, G., Beach, R., \& Smith, J. \&. (2011). Teaching and learning argumentative reading and writing: A review of research. Reading Research Quarterly, 46(3), $273-304$.

Ozerena, S., Hekimb, H., Elmasc, M. S., \& Canbegi, H. I. (2018). An Analysis of ISIS Propaganda and Recruitment Activities Targeting the Turkish-Speaking Population. International Annals of Criminology. 1-17 DOI:10.1017/cri.2018.14.

Palmer, F. R. (2001). Mood and Modality. Cambridge: Cambridge University Press. 
Pishghadam, R., Ebrahimi, S., Meidani, E. N., \& Derakhshan, A. (2020). An Introduction to Cultuling Analysis in Light of Variational Pragmatics: A Step Toward Euculturing. Journal of Research in Applied Linguistics, 44-56.

Power, M. R. (1998). Chapter 2 : Persuasion, structure and language devices. In M. R. Power, Working Through Communication (pp. 22-30). Gold Coast: Bond University.

Simons, H. W., \& Jones, J. G. (2017). Persuasion in Society (3rd ed.). New York: Routledge.

Simons, H. W., Morreale, J., \& Gronbeck, B. (2001). Persuasion in Society. Thousand Oaks London New Delhi: Sage Publications, Inc. .

Straker, D. (2002, 1 1). http://changingminds.org/principles. Retrieved August 2, 2019, from http://changingminds.org/principles/principles.htm: http://changingminds.org/principles/principles.htm

Tajvidi, G.-R., \& Arjani, S. H. (2017). Appraisal Theory in Translation Studies: An Introduction and Review of Studies of Evaluation in Translation. Journal of Research in Applied Linguistics, 3-30.

Vergani, M., \& Bliuc, A.-M. (2015). The evolution of the ISIS' language: a quantitative analysis of the language of the first year of Dabiq magazine. Sicurezza, Terrorismo e Società, 2, 7-20.

Wardhaugh, R. (2006). An Introduction to Sociolinguistics. Oxford: Blackwell Publishing.

Westmaas, R. (2017, August 22). https://curiosity.com/topics/. Retrieved August 2, 2019, from https://curiosity.com: https://curiosity.com/topics/use-amplificationto-persuade-people- without-them-realizing-it-curiosity/

Wignell, P., O’Halloran, K. L., Tan, S., Lange, R., \& Chai, K. (2018). Image and text relations in ISIS materials and the new relations established through recontextualisation in online Media. Discourse \& Communication, 1-25. DOI: $10.1177 / 1750481318766938$.

Wozniak, J. S., Woods, J., \& Lee, Y. S. (2020). The evolving self-presentation of the Islamic State, from Dabiq to Rumiyah. The Social Science Journal, 1-13. DOI: 10.1080/03623319.2020.1727242 